\title{
ENTREPRENEURSHIP ORIENTATION AS ANTECEDENT OF FAMILY BUSINESS PERFORMANCE
}

\author{
Daniel Kurniawan \\ Department of Magister Management, Universitas Ciputra, Surabaya, Indonesia
}

\begin{abstract}
The performance of a family business has become an interesting issue on the family business research. On the other hand, how to achieve that goal is still arguable. Based on literature review, entrepreneurship orientation is one of the key predictors for family business performance. This study took sample of 201 medium family company in Surabaya. Purposive sampling is selected as sample technique. The findings of this study imply entrepreneurship orientation significantly positive correlate to family business performance.
\end{abstract}

Keywords: entrepreneurial orientation, family business performance, family business

\section{INTRODUCTION}

Business sustainability, specifically family business is an area which becomes a concern for many family business experts for the last decades. Every business, especially a family business, definitely wants to remain sustainable, especially in the era of globalization, which results in competition among businesses, become even tighter. According to Wildan (2012), a sustainability strategy will give a competitive advantage for a company. A sustainability strategy will influence every value created in a company, so a company will always think about how to keep sustainable, which, in the end, will influence all operational aspects of a company. Pojasek (2007) said that a family company that can exist and sustainable as a living company is a visionary family company. This thing is interesting, considering in a family company, sustainability is a thing which becomes a hope that is hard to achieve.

One of the factors which considered influence family business sustainability is family

*Corresponding Author.

e-mail: daniel.kurniawan@ciputra.ac.id business performance. This finding was reported by Tan et al. (2002) which discovered that one of the most critical factors which influence sustainability is business performance. The more consistent a business performance for a particular period, the higher the chance of its sustainability. Kausari (2014) reported a similar finding, where a company that always monitors its performance will have an excellent position in the market and can create good sustainability.

Another factor that influences family business sustainability is entrepreneurial orientation. Quantananda (2015) researched to see the influence of entrepreneurial orientation which measured by proactiveness, innovativeness, and risk-taking which are prepared by the founder generation to the next generation. In that research, entrepreneurial orientation has Direct and indirect influences on company performance (Zahra et al., 2008; Kellermanns et al., 2008; Lumpkin \& Dess, 2001). Another research was conducted by Alimudin (2013), which observed the role of entrepreneurial orientation towards 
Daniel Kurniawan / Entrepreneurship Orientation as Antecedent of Family Business Performance /

JEE, Vol. 9, No. 1, March 2020, pp 1-8

the sustainability of small-medium enterprises (SME) competitive advantage in Surabaya city and explained that there is a relation between entrepreneurial orientation variable and business sustainability.

From time to time, a company is expected to develop skills, e.g.: risk-management skill, innovation skill to meet the needs, opportunities and threats arise, skill to anticipate direction and behavior of market change and risktolerant skill so that a company will be more encouraged to increase its business performance.

Figure 1 presents the hypothesized causal model of business performance with entrepreneurial orientation as a factor.

\begin{tabular}{|c|c|}
\hline $\begin{array}{c}\text { Entrepreneurial } \\
\text { Orientation }\end{array}$ & $\begin{array}{l}\text { Business } \\
\text { Performance }\end{array}$ \\
\hline
\end{tabular}

Figure 1 Business Performance Model Development

\section{Entrepreneurial Orientation}

Entrepreneurial orientation is defined as a bunch of processes that are used by a company to stimulate innovativeness, risk-taking and, proactiveness. Therefore, entrepreneurial orientation is more appropriate if it is measured by using 3 instruments developed by Covin and Slevin (1990), that are: First, proactiveness, is a company's ability to always be initiative in pursuing market opportunities. It consists of 3 indicators: (1) an initiative to go forward, the higher the initiative of a businessman to advance his company, the higher the proactiveness; (2) anticipate the actions of competitors, the more a businessman anticipate himself by watching the movements of his competitors, the higher the proactiveness; (3) have the speed to offer something new in the market, the quicker a businessman launch new products, the higher the proactiveness.

Second, innovativeness, is a company's tendency to support the generation of new ideas, unique and creative processes. It consists of 3 indicators: (1) the more support a company gives to products' research and development, the more innovative the company; (2) the more effort a company gives to deviate from its status quo, the more innovative the company; (3) the more support a company gives for new, innovative ideas, the more innovative the company.

Third, risk-taking, is a company's desire to have a commitment to fully use the available resources for a project, although the probability and the price for its failure are very high. It consists of 4 indicators: (1) the more a company fully allocate resources to make new things, the braver a company in risk-taking; (2) the braver a company to do have working capital loans, the braver the company in risk-taking; (3) the more frequent a company explores activities that have never been done before, the braver a company in risk-taking; (4) the more aggressive a company in decision-making, the braver the company in risk-taking.

Entrepreneurial orientation has become a highly discussed topic in the research literature regarding strategic management and entrepreneurship for the last two decades (Tang et al., 2007). Entrepreneurial orientation pushes an organization to innovate to rejuvenile offers to the market (innovativeness), take risks to try new products and services that not necessarily accepted by the market (risk-taking), and more proactive than competitors to take new opportunities in the market (proactiveness).

Baker and Sinkula (2009) stated that entrepreneurial orientation reflects the growth level of a company that is driven by the identi- 
fication and exploitation of market opportunities that have never been detected. A company that has a high degree of entrepreneurial orientation tends to be able to take advantage of an uncertain environment to be a profitable opportunity. High growth is associated with entrepreneurial behavior in an organization (Moreno \& Casillas, 2008).

\section{Family Business Performance}

The measurement of business performance has become a long discussion. According to Hofer (1983), business performance can be measured with financial indicators like sales growth, profitability, return on investment, return on sale, and return on equity (in Venkatraman and Ramanujam, 1986). However, financial indicators seem to be not enough to measure business performance so another indicator was created like an operational indicator. To produce a good business performance, positive efforts need to be made to achieve it.

As well as a family company, if company strategies were done well then it will get good and consistent business performance for a long period, especially regarding entrepreneurial orientation. The entrepreneurial spirit is crucial because it will be a booster for a company to keep creating new breakthroughs and innovations in creating better performance in the future.

In this case, no matter how good the performance of each company functional like efficiency in the production function, technological sophistication in research and development function, policies in a financial function of a company, and although many customers who buy products or services, if all of them are not integrated well, then family business performance will also not be created. Because of that, family business performance is more precise if it is measured holistically based on an instrument developed by Matiæ (2012), which is:

First, sales growth, is the rate of increase in market size, generally stated as a percentage per year. It consists of some indicators: (1) company's sales growth based on nominal, the higher the difference in gross turnover of the current year compared to the previous year, the higher the sales growth; (2) company's sales growth based on product quantity, the higher the total number of product units sold in the current year compared to the previous year, the higher the sales growth; (3) company's sales growth based on customer quantity, the higher the increase of total new customers in the current year compared to the previous year, the higher the sales growth.

Second, organization reputation, is a stakeholder evaluation of the company's reputation, based on the experience of the stakeholder of the company concerned. It consists of some indicators: (1) external reputation related to the perception of the society (how quality, feeling, and image of the company in the society), the lower the number of negative rumors of the company in mass media, the higher the degree of the company's reputation; (2) internal reputation related to the perception of the employees (how feeling and image of the company in the company's internal community), the lower the number of negative rumors of the company in employees community, the higher the degree of the company's reputation. These indicators are chosen because the company's reputation heavily determines the level of trust of external or internal parties in good relations with the company.

Third, employee satisfaction, is an emotional state, whether happy or unhappy when 
Daniel Kurniawan / Entrepreneurship Orientation as Antecedent of Family Business Performance /

JEE, Vol. 9, No. 1, March 2020, pp 1-8

an employee looks at his/her work. It consists of some indicators, which is (1) employee turnover, the higher the number of employee turnover in a company, the less job satisfaction of employees in the company; (2) Does the company pay attention to the employees' physical health; (3) Does the company pay attention to the employees' emotional health; (4) Does the company give rewards/punishments in accordance with the employees' performance achievement. This indicator is chosen because the employee's working satisfaction heavily determines his/her performance in working, and if the poor performance of all employees is accumulated, then it will decrease the company's performance.

\section{Entrepreneurial Orientation and Family Busi- ness Performance}

In a research conducted by Bossouara and Deakins (1999), a businessman who has a high level of entrepreneurial orientation will have characteristics like a need to move forward, self-internal control, tendency to take risks, a need to be free, and behave innovatively. Characteristics like these will make a company lead by a businessman with high level of entrepreneurial orientation tends to be able to take advantage of an uncertain environment to be a profitable opportunity, so that entrepreneurial orientation reflects growth level of a company driven by identification and exploitation of undetected market opportunities (Baker and Sinkula, 2009). The ability of a businessman who always sees opportunities in every occasion and his courage to take risks makes a company always sees new markets, make product development so that it increases the amount of profit generated. The times that make con- sumer preferences change resulted in every company, including a family company, needs a businessman with a high level of entrepreneurial orientation so that it can face every challenge in doing business. In other words, entrepreneurial orientation determines business performance.

There are some empirical examples of the concept. Quantananda (2015) who studied the effect of entrepreneurial orientation of food and beverage companies in Surabaya. It was found that there was a positive and significant correlation between entrepreneurial orientation which dimension was created by innovativeness, proactiveness, and risk-taking, related to the increase in business performance. Paladino (2007) also observed that sustainable product innovation or relentless entrepreneurial spirit of a businessman proved affected financial performance and customer satisfaction in the business.

Suci (2009) did research to study the relationship between entrepreneurial orientation and small medium-sized family company's performance in East Java. The finding showed that entrepreneurial orientation positively and significantly affected the managerial capability of an entrepreneur in increasing his/her business performance. In this research, Suci (2009) stated that there are 4 important things that need to be noticed by a businessman so that he/she can master a good managerial capability, so the business performance is maintained. First, he/ she has a desire to achieve a strong goal. Second, he/she has confidence and a picture of the level of success that can be achieved from a business. Third, he/she has a high level of confidence in every action and decision that is done. And fourth, he/she has a character of openness, particularly related to his/her surrounding environment. 
Considering the previous findings across literature, this study proposes the following hypothesis:

Hypothesis 1. Entrepreneurial orientation is positively related to family business performance

\section{METHOD}

\section{Sample and Procedure}

A total of 201 people from middle-class family businesses in Surabaya had participated in this study. The method of collecting and selecting the samples are purposive sampling, as certain qualification need to be fulfilled in order to partake the study. The questionnaire itself was delivered through family businesses in Surabaya.

\section{Measure}

All measures consist of five-points Linkert scales. In the questionnaire was given some alternative existing scenarios of conditions in the family business, then respondents chose which condition was the closest to the alternatives. In every question, there are 5 answers for alternative scenarios, from number 1 for the most unprofitable scenario for a family company, to number 5 to describe the most ideal condition for the development of a family company.

\section{Entrepreneurial Orientation}

To measure the entrepreneurial orientation, the indicators used in this research are 1) proactiveness, 2) innovativeness, 3 ) risk-taking.

\section{Business Performance}

To measure the family business performance, the indicators used in this research are
1) sales growth, 2) organization reputation, 3) employee satisfaction.

\section{Data Analysis}

All the hypotheses were tested using simple linear regression. This is a statistical test that predicts a dependent variable based on an independent variable. For this research, the entrepreneurial orientation is an independent variable, and the business performance is a dependent variable.

\section{RESULTS}

\section{Assessing the Structural Model}

\section{Direct Effects}

As the instruments have been confirmed as valid and reliable, the next step will be assessing the structural model. Simple linear regression was used to assess the ability of a control measure (entrepreneurial orientation) to predict business performance. There was a strong, positive correlation between two variables, $r=$ 0.896, $n=201, p<.001$, with high levels of entrepreneurial orientation associated with higher levels of family business performance. Business performance could be predicted from entrepreneurial orientation by the following formula: business performance $=0.56 *$ entrepreneurial orientation $+37.110, R^{2}=0.801$. The value of A $(0.56, p<.001)$ and B (37.110, $p<.001)$ in the equation is significant and has an effect to business performance.

By using ANOVA, we know whether there is an effect from entrepreneurial orientation to family business performance so that the regression equation can be used to predict. By looking at the result, we can know that this regression 
Daniel Kurniawan / Entrepreneurship Orientation as Antecedent of Family Business Performance /

JEE, Vol. 9, No. 1, March 2020, pp 1-8

equation can be used to predict business performance, $F(1,199)=806.697, p<.001$.

\section{Discussions}

Prior research has suggested that entrepreneurial orientation has a positive impact on business performance. This hypothesis was supported by the work of Suci (2009) in which her research was based on small medium-sized family companies in East Java and Quantananda (2015) in which his research was based on food and beverage companies in Surabaya. In this research, we found that there is a positive and significant relationship between entrepreneurial orientation and family business performance. This result provides additional empirical evidence in family business settings. Our study found consistent findings with previous research as the relationship between entrepreneurial orientation and family business performance is strong and positive. When we take a deeper look into the indicators between two measures, we can demonstrate this positive impact in detail.

Proactiveness has a positive impact on business performance. If a company has the initiative to go forward, it will find any available market opportunities and increase the company's sales growth. This action makes more customers attracted to its products. Furthermore, if a company can plan a good strategy to anticipate the actions of competitors, it will overcome challenges in the market, create a greater opportunity to make products or services of this company have a higher value for the customer, and increase its reputation. And, if a company can have lots of new products, it will raise the brand awareness of this company and have a positive impact on the innovativeness of the company and increase employee satisfaction because the employees can give meaningful contributions to the company and the company can give rewards for these contributions.

Innovativeness has a positive impact on business performance. If a company gives more support to the product's research and development, it will create lots of new products, increase the quality of the products, and increase customer's trust and make more customers eager to afford this company's products due to the diversity and quality of the products. If a company gives more effort to take a new challenge and deviates from its status quo, it will challenge the company to create a new and fresh strategy to overcome the challenge, and it will push the company to have more innovations and breakthroughs and leads to sales growth. And if a company can give supports to new and innovative ideas, it will increase its reputation because the company can provide and develop better technologies, techniques, and strategies than its competitors. And it will increase employee satisfaction because employees have more freedom to express their ideas, have resources to create their ideas, the company facilitates this development. This will create a good environment to have meaningful contributions.

Risk-taking also has a positive impact on business performance. If a company fully allocates more resources to make new things, it will push the innovativeness of the company, and it will increase diversity and quality of its products. This will increase its sales growth. If a company is braver enough to have working capital loans, then it will provide more resources to develop new things, increase promotions of its products, and train employees to increase their skills. This will increase reputa- 
tion and employee satisfaction. However, a company needs to consider the side effects of having working capital loans and carefully assess the advantages relative to the risk taken. If the advantages relative to the risk is low, then the company needs to consider other options. If a company explores new activities more frequently, it will increase its opportunity to have new ideas, innovations, and find a new gap which has not been seen by other competitors. This will increase its business performance as a whole in every aspect. And, if a company is more aggressive in decision-making, it will push its proactiveness and innovativeness in order to increase advantages among other competitors. This will increase its reputation and sales growth. However, a company should assess the risk and consequences of every decision it makes.

\section{REFERENCES}

Alimudin, A. (2013). Pengaruh Orientasi Wirausaha terhadap Keunggulan Bersaing Berkelanjutan dan Kinerja Pemasaran Usaha Kecil Sektor Perdagangan (Consumer Goods) di Kota Surabaya. Sustainable Competitive Advantage (SCA), 3(1).

Baker, W. E., \& Sinkula, J. M. (2009). The Complementary Effects of Market Orientation and Entrepreneurial Orientation on Profitability in Small Businesses. Journal of Small Business Management, 47(4), 443-464.

Boussouara, M., \& Deakins, D. (1999). Market-based learning, entrepreneurship and the high technology small firm. International Journal of Entrepreneurial Behaviour \& Research, 5(4), 204-223.

Covin, J. G., \& Slevin, D. P. (1990). New Venture Strategic Posture, Structure, and
Performance: An Industry Life Cycle Analysis. Journal of Business Venturing, 5(2), 123-135.

Kausari, A. (2014). Pengaruh Kepemilikan Keluarga Terhadap Kinerja Perusahaan dengan Mempertimbangkan Strategi Bisnis sebagai Variabel Pemoderasi pada Industri Makanan dan Minuman di Bursa Efek Indonesia. [Doctoral Dissertation, Universitas Muhammadiyah Surakarta].

Kellermanns, F. W., Eddleston, K. A., Barnett, T., \& Pearson, A. (2008). An Exploratory Study of Family Member Characteristics and Involvement: Effects on Entrepreneurial Behavior in the Family Firm. Family Business Review, 21(1), 1-14.

Lumpkin, G. T., \& Dess, G. G. (1996). Clarifying the Entrepreneurial Orientation Construct and Linking It To Performance. Academy of Management Review, 21(1), 135-172.

Matiæ, I. (2012). Measuring the Effects of Learning on Business Performances: Proposed Performance Measurement Model. The Journal of American Academy of Business, Cambridge, 18(1), 278-284.

Moreno, A. M., \& Casillas, J. C. (2008). Entrepreneurial Orientation and Growth of SMEs: A Causal Model. Entrepreneurship Theory and Practice, 32(3), 507-528.

Paladino, A. (2007). Investigating the Drivers of Innovation and New Product Success. Journal of Product Innovation Management, 24, 534-553.

Pojasek, R. B. (2007). A Framework for Business Sustainability. Environmental Quality Management, 17(2), 81-88.

Quantananda, E. (2015). Pengaruh Orientasi Kewirausahaan pada Perusahaan Makanan dan Minuman di Surabaya. AGORA, 3(1), 706-715. 
Suci, R. P. (2009). Peningkatan Kinerja Melalui Orientasi Kewirausahaan, Kemampuan Manajemen, dan Strategi Bisnis (Studi pada Industri Kecil Menengah Bordir di Jawa Timur). Jurnal Manajemen dan Wirausaha, 11(1), 46-58.

Tan, K. C., Lyman, S. B., \& Wisner, J. D. (2002). Supply Chain Management: A Strategic Perspective. International Journal of Operations and Production Management, 22(5-6), 614-631.

Tang, J., Tang, Z., Zhang, Y., \& Li, Q. (2007). The Impact of Entrepreneurial Orientation and Ownership Type on Firm Perfor- mance in The Emerging Region of China. Journal of Developmental Entrepreneurship, 12(04), 383-397.

Venkatraman, N. \& Ramanujam, V. (1986). Measurement of Business Performance in Strategy Research: A Comparison of Approaches. Academy of Management Review, 11(4), 801-814.

Zahra, S. A., Rawhouser, H. N., Bhawe, N., Neubaum, D. O., \& Hayton, J. C. (2008). Globalization of Social Entrepreneurship Opportunities. Strategic Entrepreneurship Journal, 2(2), 117-131. 